\title{
How can Corporations Contribute to the Community through Environmental Education? : Focusing on Partnerships between Corporations and Universities in Korea
}

\author{
Eunjeong $\mathrm{Ju}^{1} \&$ Shinho Jang ${ }^{2}$ \\ ${ }^{1}$ Convergence and Creativity Education Research Center, Seoul National University of Education, Seoul, Korea \\ ${ }^{2}$ Department of Science Education, Seoul National University of Education, Seoul, Korea \\ Correspondence: Shinho Jang, Department of Science Education, Seoul National University of Education, Seoul, \\ Korea. E-mail: shinhojang@snu.ac.kr
}

Received: March 28, 2016

doi:10.5539/ies.v10n8p116

\begin{abstract}
The goal of this study was twofold: first, to determine the effectiveness of providing environmental education in collaboration between a company and a university, and, second, to describe perspective that the environmental education community has developed through close communication with stakeholders in environmental education. For the study, we observed the "Green Keeper" project's collaborative progress and collected various quantitative and qualitative data on the project for three years. Participating students' knowledge of and concern for the environment significantly increased after participation in the project $(\mathrm{p}<.01)$. We discerned that changes in the children spread to the community as well. Green Keeper project participant satisfaction ranged from 3.52-4.32 over three years, indicating a consistently high level. Satisfaction rose each year because the project steadily evolved through collaboration between the university and the company with additional feedback from the community. This project found several advantages to collaborative environmental education, such as effective community environmental education, encouraging environmental education in schools, and investment in the future of the company.
\end{abstract}

Keywords: environmental education, corporate environmental responsibility, collaboration between university-corporation, community

\section{Introduction}

In recent years, as the seriousness of problems such as climate change and hazards to the environment have received more emphasis, corporate environmental responsibility (CER) has been discussed more frequently (DesJardins, 1998; Holtbrügge \& Dögl, 2012; Maxwell, Rothenberg, Briscoe, \& Marcus, 1997; Rondinelli, \& Berry, 2000). Since the World Commission on Environment and Development was published in 1987, there has been a fierce debate over why and how strategic actions to sustain the Earth's ecosystem should be integrated (Mazurkiewicz, 2004). Corporate environmental responsibility (CER) means that companies should care for the environment or take action to mitigate their negative impact on the environment (Gunningham, 2009). In recent times, the importance of corporate environmental responsibility has received more and more emphasis (Mazurkiewicz, 2004; Bortree, Ahern, Smith, \& Dou, 2013).

Education is no exception to the expansion of corporate environmental responsibility. Environmental education has a significant social and environmental impact and can foster civic literacy. Environmental education is fairly attractive for corporations. It sends a corporate message to the public which can especially influence individuals who are concerned about the environment (Reyes \& Twose, 2002; Bortree et al., 2013). Environmental education enables corporations to balance corporate and public values (Maxwell, Rothenberg, Briscoe, \& Marcus, 1997). Additionally, companies that provide environmental education project a positive image by giving a portion of their revenue back to the community (Miles \& Covin 2000).

However, there are several inherent limitations for companies involved in environmental education. First, because environmental education is not a top priority for corporations, they don't develop expertise in this area. Since the 1960s, when environmental education began to be discussed, instructors and researchers of environmental education have developed a variety of educational topics and teaching methods (Palmer, 2002). 
Direct attempts by corporations to provide such education raise questions about the effects of education provided without a foundation of knowledge about environmental education and educational methods, even with the best of intentions. Such companies also are able to deliver a unilateral and prejudicial message about the environment, seeking to improve their own reputation through such social projects (Beder \& Beder, 2002). These companies are likely to choose the contents of an environmental message based on the benefits to themselves (Miles \& Covin 2000). When a company conducts its own environmental education, the message could be biased in favor of the company. It is particularly critical to avoid bias in educational messages targeted at young children who cannot judge the bias of an environmental message.

Universities, however, have several advantages qualifying them to act as a partner for corporate environmental education. Cooperation between companies and universities has attracted much attention recently because it provides opportunities for graduates to work for companies, providing education and research, while corporations, meanwhile, provide universities with a place to practically test their theoretical research and education (Tener, 1996; Lee, 2000; Slotte \& Tynjälä, 2003). Cooperation between universities and companies in this study differs slightly from the norm. In this study, corporations cooperated with university educational experts to conduct environmental education as a way of fulfilling their corporate social responsibility. In this study, the University of Education partnered with corporations to provide a primary school teacher and to focus on elementary education and research. University of Education students and professors are elementary education experts and have close ties to real, practical elementary education.

Previous studies have examined the process, advantages, and effect of corporate-university collaboration (e.g. Siegel, 2003; Perkmann \& Walsh, 2009) or collaborative environmental education with the community (Tali, 2004; Vaughan, 2003; Dori, \& Tal, 2000; Newton, 2001). However, the possibility that university-corporate collaboration can lead to community environmental change has not yet been sufficiently studied. Corporate environmental responsibility will be emphasized even more in the future. When companies want to provide environmental education, they need methods for achieving authentic environmental advantages, and cooperation with a university and with the community can provide that.

In this study, we used a variety of data sources to closely observe the process of launching a collaborative environmental educational project between a company and the University of Education in Korea. The goal of this study was to determine the effectiveness of collaborative environmental between company and university and to describe the perspective that the environmental education community has developed through close communication with stakeholders in environmental education. This study also seeks to present a desirable role model for companies wishing to contribute to the community through environmental education.

\section{Project Overview: Green Keeper}

This environmental education project called "Green Keeper" has been promoted since 2010 as part of the corporate social responsibility of Hyundai Steel (H-steel) in South Korea. An NGO group involved in environmental field co-work was involved in the initial project, but in 2011, the Convergence and Creativity Education Research Center of the Seoul National University of Education in Korea entered into a partnership with H-steel, and this partnership provided children's environmental education from 2011 to 2013. This study focused on the collaboration between the company and the university, so we observed the project's progress and collected various data on the project from 2011 to 2013.

The cities of In-cheon, Dangjin-gun, and Po-hang, where H-steel is located, were the target areas for the project. In-cheon, which is located near Seoul, the capital of South Korea, is the most urban of the three target cities. It has the fourth largest population of any city in South Korea. Po-hang is located in the southeastern part of Korea and is a medium-sized city with 500,000 residents. Dang-jin is smaller, with a population of about 160,000, and it is less urban than the other two cities (KOSIS, 2016).

The Seoul National University of Education, a college for fostering and retraining elementary teachers, signed a partnership with $\mathrm{H}$-steel. The Elementary teacher certificate can be given to person who is received regular training in "the department of elementary education." The department of elementary education exists in a total of 13 universities in Korea, and 11 of them are called a "University of Education." All Universities of Education are financed by the government, and they are scattered over the country. They graduate about 2,000 to 3,000 licensed elementary teachers each year. Those universities work closely with school elementary teachers and continuously research new content and methods for primary education, including environmental education.

In this partnership, the University of Education was the elementary education expert and interacted closely with teachers, choosing curriculum, learning methods, educational content, time allocation, and instructors. The Corporation designated educational target areas, set the number of participants, and provided funds for materials 
and programs. The objectives, methods, and form of the program, including the program and structure of the overall project, were developed by the universities and companies together. In that process, the school that included the participating teachers, students, and parents played an important role in the development of the project Green Keeper by assessing the project.

In the first year of the project, the main theme of program was "Global Warming," and there were two detailed programs: 1) Environmental Class for Kids (ECK) and the Environmental Summer Camp (ESC). The ECK program consisted of five lessons, for which elementary school teachers, with training and screening by university researchers, selected the contents and learning methods. Instructors trained in the program, visited the school and taught the participating students. In the ESC, 115 students were selected to visit the university and participate in a variety of environmental education programs and projects for two days.

In 2012, the second year, the Training for Elementary Teachers (ETT) and Environmental Action Portfolio (EAP) were added to the program. The EAP program complemented the F, consisting of classes in which students collected photos, pictures, and articles about topics discussed in ECK lectures to create a portfolio. These portfolios were displayed in an exhibition at the end of program. The ETT was a program for classroom teachers of participating students. It included the environmental lectures used in the Green Keeper program as well as other methods and materials for environmental education. Therefore, in the second year (2012), the program's educational targets were not only the elementary students but also their teachers.

In the third year, 2013, the ESC participants expanded again to include family members of participating students, including parents. It became a kind of family environmental camp.

\section{Method}

\subsection{Participants}

The company proposed the initial number of participants in the project. A total of 975 elementary students from 23 elementary schools in three regions were involved in the project the first year, 2011. In the second year, 2012, 524 students from four schools in three regions participated. The number of target schools and students was reduced but the scope of environmental education was expanded to include elementary teachers. In the third year, 2013, the same four elementary schools were involved in the project as in 2012; 477 students and 19 teachers participated. An additional 74 family members of the students, including parents, participated in the family environmental camp.

\subsection{Data Sources and Analysis}

The researchers were directly involved in the planning and progress of the Environmental Education Project Green Keeper. The goal of this study was to determine how collaborative environmental education projects between companies and universities affect community environmental education. We observed closely the changes in topics, range of participants, and teaching methods for three years, and we collected data from the participants.

\subsubsection{Quantitative Data}

We used CHEAKS (Children's Environmental Attitude and Knowledge Scale), developed by Leeming, Dwyer, and Bracken (1995), to verify the effectiveness of the program's environmental education in the second year.

The knowledge portion of the scale was excluded, and contents related to our project were extracted, such as general knowledge about the environment, energy, pollution, waste and recycling, water, and global warming. The test used a five-point Likert scale. Questions that did not translate well into Korean or the Korean approach to environmental education were modified through discussion with researchers. A 12-item true-false basic environmental knowledge test was developed in discussion with Green Keeper program development staff. The contents of our test were verified by three professors with $\mathrm{PhDs}$ in environmental and science education. The same tests were administered before and after participation in the educational program. The results of the test showed students' attitudes toward and knowledge of the environment. The average score and standard deviation on a scale of 5 were calculated. Scores from before and after the program were compared using a paired t-test.

The satisfaction of participating students, teachers, and parents with the program was also examined through an annual questionnaire. This survey, which was completed by all participating students and teachers in the first two years and by the parents in the third year, used a five-point Likert scale. The mean and standard deviation of the results were calculated.

\subsubsection{Qualitative Data}

During the second year, randomly selected portfolios of 80 participants were closely examined and analyzed. 
The portfolios were created as part of the activities during the environmental education program. In-depth interviews were conducted with 30 volunteer students, taken from among those who submitted portfolios on program effectiveness and satisfaction.

Each year, around 20 classroom teachers participated in the program, with a total of 60 teachers participating over three years. We researched their opinions on the environmental education collaboration between the company and the university through annual semi-structured interviews and questionnaires. The teachers offered a professional perspective and could assess the effect of the collaboration on their community, even though they also participated in the project. Their feedback and evaluations offered important suggestions for improving the program from year to year.

Additional data were collected from parents who participated in the third year. They discussed the educational effectiveness and significance of the "Green Keeper" project at the environmental camp. We recorded their opinions and suggestions after obtaining their consent.

All the information collected from students, teachers, and parents was transcribed. Qualitative data, such interview transcriptions and student portfolios, was analyzed by extracting opinions which were presented repeatedly.

\section{Results}

\subsection{The Educational Effect of "Green Keeper"}

The participating students increased their knowledge of and concern for the environment through the Green Keeper project. This educational effect also spread to the wider community through the families of the students.

\subsubsection{Change in Children's Attitudes toward the Environment}

Table 1 shows student attitudes toward the environment before and after participating in the Green Keeper project. Environmental knowledge and attitude for the environment of the 492 participating students (discounting the missing values) significantly increased after participation in the project. The students' general attitude toward the environment (General) increased significantly, from 3.16 point to 3.49 after involvement in the project $(\mathrm{t}=-8.328, \mathrm{p}<.01)$. Environmental attitudes in the area of Energy also increased significantly, from 3.48 points to 3.77 points $(\mathrm{t}=-8.316 \mathrm{p}<.01)$. Students' attitudes toward Pollution $(\mathrm{t}=-9.388)$, Recycling $(\mathrm{t}=$ -7.237), Water $(\mathrm{t}=-7.385)$, Global warming $(\mathrm{t}=-2.687)$ also tended to increase significantly after participation in the project $(\mathrm{p}<.01)$. Student results on the environmental knowledge test also demonstrated a statistically significant increase, from 3.24 points out of 5 to 3.50 points $(t=-5.922, p<.01)$.

Table 1. Attitude and knowledge toward environmental issues

\begin{tabular}{|c|c|c|c|c|c|c|}
\hline & & & $\mathrm{M}$ & SD & t-value & $\mathrm{P}$ \\
\hline \multirow{12}{*}{$\begin{array}{c}\text { Environmental } \\
\text { Attitude }\end{array}$} & \multirow{2}{*}{ General } & Pre & 3.16 & 0.81 & \multirow{2}{*}{-8.328} & \multirow{2}{*}{.000} \\
\hline & & Post & 3.49 & 0.76 & & \\
\hline & \multirow{2}{*}{ Energy } & Pre & 3.48 & 0.69 & \multirow{2}{*}{-8.316} & \multirow{2}{*}{.000} \\
\hline & & Post & 3.77 & 0.62 & & \\
\hline & \multirow{2}{*}{ Pollution } & Pre & 3.22 & 0.86 & \multirow{2}{*}{-9.388} & \multirow{2}{*}{.000} \\
\hline & & Post & 3.70 & 1.00 & & \\
\hline & \multirow{2}{*}{ Recycling } & Pre & 3.62 & 0.83 & \multirow{2}{*}{-7.237} & \multirow{2}{*}{.000} \\
\hline & & Post & 3.92 & 0.82 & & \\
\hline & \multirow{2}{*}{ Water } & Pre & 3.53 & 0.83 & \multirow{2}{*}{-7.385} & \multirow{2}{*}{.000} \\
\hline & & Post & 3.85 & 0.82 & & \\
\hline & \multirow{2}{*}{ Global warming } & Pre & 3.31 & 0.69 & \multirow{2}{*}{-2.687} & \multirow{2}{*}{.007} \\
\hline & & Post & 3.42 & 0.77 & & \\
\hline \multirow{2}{*}{\multicolumn{2}{|c|}{ Environmental Knowledge }} & Pre & 3.24 & 0.72 & \multirow{2}{*}{-5.922} & \multirow{2}{*}{.000} \\
\hline & & Post & 3.50 & 0.71 & & \\
\hline
\end{tabular}

When interviewed teachers observed the daily life of students, they stated that students became increasingly interested in environmental issues and more actively involved in environmental activities after participation in the project.

Teacher C in Dang-jin: There is one naughty child in my class; he has become increasingly interested in the 
environment. So I uploaded his picture of environmental practice. He said that he would water the plants in our class after participation in the Green Keeper project.

Teacher C described this student as "naughty," which means that the teacher has a negative opinion about the student's usual attitude toward learning. Nevertheless, the student offered to water the plants, which to the teacher understood as an enhanced environmental or ecological sensitivity and empathy with living things. Furthermore, Teacher $\mathrm{C}$ attributed this development to participation in the Green Keeper project.

In his portfolio, Student $\mathrm{F}$ described an everyday scene during which he thought about what he had learned through the Green Keeper project. During a Green Keeper lecture, the student was indirectly exposed (through photography) to the death of fish due to water pollution. He empathized with the suffering fish, and eventually he recognized that he is part of the environment through realizing that water may be contaminated by him.

I went to a valley with my family to see the beautiful scenery. When I saw the small fish swimming through the clean water, I felt refreshed. In this joyful moment, a photo came into my mind. It was the photo of the fish killed by the pollution in the river...It made my heart hurt to think that we contaminate our precious water ourselves.

- From the portfolio of Student F

In the interview, Student $G$ described his learning experience with the pollack. In the Green Keeper project, he learned that the pollack's habitat is changing due to global warming. Student G was very familiar with pollack as a common food. He empathized with the fish's loss of their habitat. When Student G learned that the pollack's habitat had changed due to his actions, he realized that he was part of the environment.

Student G: I learned that the habitat of pollacks was moving north. It hurt me to think that they lost their place to live and had to go north because we contaminated it.

The researchers and teachers at the university who developed the environmental education programs in this study used their expertise in elementary education to develop effective teaching strategies for the program. One such strategy is context-sensitivity (Agyeman, 2003). In the Green Keepers program, familiar material was used to help students connect their life experiences to learning about the environment. The use of familiar content helped students to experience empathy, increasing their environmental sensitivity. Promotion of environmental sensitivity was an important link which led to changes in environmental attitudes and practice (Hungerford \& Volk, 1990). Environmental sensitivity played a crucial role in improving the students' attitudes toward the environment.

\subsubsection{Diffusion of the Environmental Change from Children to Community}

Changes in the children involved in the Green Keeper projects tended to spread to the community from the students' homes. Student H's portfolio describes a scene encouraging positive environmental action. He made and used an environmentally-friendly detergent after learning about water pollution in the Green Keeper project. He was advised to reduce detergent use and save water at home.

When my mom did the dishes, I told her to use less soap. I gave my brother a cup of water for brushing his teeth. I turn off the water while washing my face. I also told my mom to re-use bathwater for washing clothes.

- From the portfolio of Student $H$

Student H's participation in the Green Keepers project changed his perception of water usage. He learned about environmentally protective actions he could take, and his knowledge spread through his family to his brother and mother. Student $\mathrm{H}$ has changed through the environmental education project, and this change can be expected to spread to the community through his family (Tali. 2004; Ballantyne; Fien, \& Packer, 2001). Student H was a mediator for community environmental education.

Other participating students, Students I and J, also stated in their interviews that their changed environmental awareness was transmitted to their families. They also induced environmental change through family projects.

Student I: The light of every room in my house is almost always turned on. I thought that was not necessary. My family tended to leave unused devices plugged in, so I told my mom that leaving devices plugged in wastes electricity.

Student J: I told my older sister to close the refrigerator door. She tends to leave the door open. I suggested to my mom that, instead of heating the house more in cold weather, we wear warmer clothes.

Students I and J were learning about energy. So, they noticed environmentally-unfriendly behaviors, such as leaving the refrigerator door open or turning on all the lights at home. They not only modified their own behavior but also recommended environmentally positive actions to their family members. The environmental 
awareness and behavior of Student I spread to his family as members of a community. Formal and informal community education is difficult. However, education of students can easily spread to the community (Tali, 2004; Damerell, Howe, \& Milner-Gulland, 2013).

\subsection{Evaluation of the Collaborative Environmental Project}

\subsubsection{Changes in Satisfaction}

The satisfaction of Green Keeper project participants from the first year to the third year ranged from 3.52-4.32 (on a five-point Likert scale) indicating a consistently high level (Table 2). Participant satisfaction tended to increase over the three years. Student satisfaction increased from 3.83 in the first year to 4.30 in the second and third year. Teacher satisfaction averaged 3.52 in the first year and increased to 4.32 in the second year. Teacher satisfaction also generally tended to increase, although it decreased to 4.13 in the third year. Parent satisfaction was also high (4.27), though we were only able to collect data from parents in the third year.

Table 2. Changes in satisfaction over the duration of the project

\begin{tabular}{lcccc}
\hline Participants & Year & Mean & S.D & N \\
\hline \multirow{4}{*}{ Teachers } & 1st year & 3.52 & 0.30 & 21 \\
\cline { 2 - 5 } & 2nd year & 4.32 & 0.41 & 17 \\
\cline { 2 - 5 } & 3rd year & 4.13 & 1.36 & 16 \\
\hline \multirow{4}{*}{ Students } & 1st year & 3.83 & 0.90 & 541 \\
\cline { 2 - 5 } & 2nd year & 4.30 & 0.93 & 498 \\
\cline { 2 - 5 } & 3rd year & 4.30 & 0.88 & 447 \\
\hline Parents & 3rd year & 4.27 & 0.70 & 370 \\
\hline
\end{tabular}

Satisfaction rose each year because the project steadily evolved through collaboration between the university and the company with additional feedback from the community. In the first year, the early stages of the project, the company determined the range of participants, the theme of the project, and the operational methods (Table 3). However, participant satisfaction gradually increased (as shown in the table) because the project evolved and changed through discussions and collaboration by the company and the university.

As shown in Table 3, the range of participants, the program's main theme, included topics, the collaborative relationship, and the community's perception of the program all steadily evolved through collaborative discussions between the university and the company and through community feedback. For example, in the early stages of the project, the company proposed an opening ceremony, which all participants could join, during which the project goals and company CSR could be presented.

However, most teachers preferred a different approach. Such differences of opinion occurred due to the company's lack of professional knowledge about environmental education and to the different perspectives of the company and the university. Following discussions between the company and the university, the launching ceremony, which promoted the company but not the program, has been excluded since the second year. The company also expected that only students would participate in the project, without considering the possibility that the impact of environmental education would spread to the community. Again, after discussions between the company and the university, the program was expanded to include more participants. In the second year, the university proposed that classroom teachers be included in the program, because the university already recognized their powerful influence on the education of students and the community. After three years, the company also recognized the important of environmental education for the community and proposed the inclusion of parents as participants in the program as well.

Some teachers who participated in the second year of the project proposed a similar idea to the one put forward by the company: that the programs expand into a family event.

Teacher D in In-chon (participated in 2012): Budget permitting, the Environmental Summer Camp will be a valuable family vacation even for only two days and one night. We try to teach good environmental habits, but it is useless unless it's also supported at home. Children say, "My mom keeps doing the opposite of what the teacher does"...I think the parental perspective is very important to environmental education. I think that a family camp for students and parents would benefit them. Moms may think, "My kid does it like this" or "The company that supports my kid's school did this." This is important to the company because the parents are also potential customers. 
Teacher D, who participated in the project in In-chon, also proposed a family environmental camp for parents and students. He suggested that it would improve both parents' and children's environmental awareness and help the community become more sustainable. It also benefits the company because parents are potential customers. This kind of feedback from community members was used constantly throughout the project to make decisions and changes. Several discussions led to the expansion of the project in the third year to include parents as participants.

The family Environmental Summer Camp (ESC) was held in the third year. The father of Student L, one of the parents who participated in the ESC, said that the camp was meaningful to him and recommended it to other families:

Father of Student L: I had talked with my kids about the environment before. They thought that Mom should always separate the trash and turn off the light and the faucet. After coming here (ESC), they do those things themselves. They separate the trash and turn off the light. I think environmental programs like this camp are helpful for them. I want to recommend it to other families.

Table 3. The evolution of the project

\begin{tabular}{|c|c|c|c|}
\hline & 1 st year & 2nd year & 3 rd year \\
\hline Included Programs & $\begin{array}{l}\text { - ECK } \\
\text { - ESC (only students) }\end{array}$ & $\begin{array}{l}\text { - ECK } \\
\text { - ESC (only students) } \\
\text { - ETT } \\
\text { - EAP }\end{array}$ & $\begin{array}{l}\text { - ECK } \\
\text { - ESC (students and their families) } \\
\text { - ETT } \\
\text { - EAP }\end{array}$ \\
\hline Scope Participants & - Only students & $\begin{array}{l}\text { - Students } \\
\text { - Teachers }\end{array}$ & $\begin{array}{l}\text { - Students } \\
\text { - Teachers } \\
\text { - Student families }\end{array}$ \\
\hline $\begin{array}{l}\text { Education } \\
\text { Community }\end{array}$ & $\begin{array}{l}\text { - Community not included } \\
\text { - Indirect environmental education for } \\
\text { community through students }\end{array}$ & $\begin{array}{l}\text { - Community partially included } \\
\text { (teachers) } \\
\text { - Indirect environmental } \\
\text { education for community }\end{array}$ & $\begin{array}{l}\text { - Community included } \\
\text { - Direct \& indirect environmental } \\
\text { education for community }\end{array}$ \\
\hline Main Theme & $\begin{array}{l}\text {-Global warming } \\
\text { (suggested by company) }\end{array}$ & \multicolumn{2}{|c|}{$\begin{array}{l}\text { - General Environmental Issues } \\
\text { (It can be approached based on daily- life and environmental sensitivity) }\end{array}$} \\
\hline
\end{tabular}

\subsubsection{Advantages of Collaborative Environmental Education}

Effective environmental education of the community

Teachers and parents who participated in the Green Keeper project positively assessed the collaborative between the university and the company. In particular, the participants expressed high satisfaction with the hands-on educational activities developed by university staff.

Father of Student L: Since the environment is a difficult subject, I expected the program would be based on lectures. However, there were many activities; those were really good. I hope they create even better programs in the future (ESC in second year).

Mother of Student M: Everyone here is concerned about the environment. However, because of various problems, we cannot always take action. I always wanted to educate my kids about the environment, but I did not know of an appropriate program like this (camp). If you develop more environmental educational programs or systems, it would be helpful for us.

Lecture-centered classes, without hands-on activities, are not effective and do not instill environmental values. Effective environmental education programs should connect to learners' daily lives (Athman \& Monroe, 2001). Professionals with experience in primary education based the Green Keepers environmental educational program on activities and materials from students' everyday life.

The activity- and sensitivity-based programs aroused participant interest, and learning materials that connected to their everyday life reminded participants to be sensitive to the environment (Hungerford \& Volk, 1990; Athman \& Monroe, 2001). These trends in the development of the program improved educational success and participant assessment. 
Encourage environmental education in school

Elementary school teachers involved in the project commonly said that it is hard to efficiently conduct environmental education in a school setting.

Teacher P in Dang-jin: When I first heard about the project, I thought that would be very formal. I changed my mind after participating. The lecturer from the university team used special contents and encouraged my students to learn actively. Actually, if I tried to prepare those activities, it would have taken extra money and time. So, it was very good for the children to have professional educators leading various environmental educational activities...

This project is affiliated with Hyundai Steel, which is in our area. The children did not know what companies were located in our area. However, they learned about a company in our area and developed a more positive impression of the company through this project.

Teacher E in In-chon: Generally, when we try to do environmental education in the school, we have no choice but to use computer slides (because we do not have sufficient supplies and materials). It was very meaningful that the students could actually experiment and, on their own, operate tools to study the environment.

Teacher P in Dang-jin insisted that time and financial resources must be invested in interesting and effective environmental education. However, currently, that kind of resources and time are not being invested in environmental education in elementary schools, so learning about the environment is conducted by rote. He thought that the collaborative project with company and university offered a great opportunity for environmental education in schools.

Teacher $\mathrm{E}$ in In-chon was also concerned about the current condition of elementary environmental education, and he thought that educational projects like Green Keeper offer a viable alternative. In South Korea, "Environmental Education" is not an independent subject in the national curriculum at the elementary level. It is just one of many options under "Creative Experience Activities" (MOE, 2015). Therefore, it depends on the teacher whether environmental education will be conducted or not. A collaborative project like Green Keepers offers an alternative for environmental education in elementary schools.

Investment in the future of the company

In addition to benefiting students and schools, collaborative projects in environmental education also offer several advantages for the company. Some parents presented them in their interviews.

Mother of Student N: When I visited the Hyundai Steel Company, I wondered how the company tries to improve the environment. That is, are they supporting environmental activities or making a real effort? You know we live in the area near Hyundai Steel.

The mother of Student N said that she had questions about the company's sustainability efforts. As a member of the nearby community, she wanted to know what efforts the company was making to fulfill their environmental responsibility.

Another parent hoped that the atmosphere of this project would spread to other companies:

Father of Student M: This is a kind of social atmosphere. Hyundai Steel's involvement in this collaborative project makes a good impression on us. I hope that other companies join similar projects and that this atmosphere spreads.

The father of Student M predicted that this environmental collaboration would improve H-steel's corporate image and make them a model leading other businesses to volunteer to start similar projects. He hoped that these activities would spread to the entire business.

One reason that companies like Hyundai Steel are currently advocating for better management of the environment is that an environmentally friendly image improves their overall public image (Davis, 1994). This project had a positive impact on environmental education in the community, and it improved H-steel's public image as an environmentally friendly business. Through parent interviews, we determined that involvement in such a project improves a company's public image more effectively than ads conveying unilateral massages.

A teacher in Po-hang focused on the future in his interview:

Teacher $O$ in Po-hang: This is an investment to foster the talent of the future...Children vaguely remembered something about Hyundai Steel, even though direct information about the company was not included in the Green Keeper classes. I think those children could grow up to be Hyundai Steel employees. It is a good long-term investment. 
He suggested that business support of environmental education is an investment in the future human resources of the company. It can potentially lead to significant long-term profit.

\section{Discussion}

As adults, the parents of participating students have a significant and practical impact on environmental policy, so changes in their attitudes towards the environment are very important for society's sustainability.

Environmental education targeting the whole community could have a similarly powerful effect (Tali, 2004). However, it is difficult to offer direct environmental education for adults due to the lack of of time, financial resources, opportunities to meet, motivation to actively participate, and so on (Ballantyne, Connell, \& Fien, 1998). Adult environmental education, therefore, mostly relies on the media, but it is not very effective (Brothers, 1990). This is why Ballantyne et al. (1998) suggested that children's environmental education can be a catalyst for environmental change in the community.

In our study, we could observe that the children who participated in the Green Keeper project played the role of mediators between environmental education and adults in the community. The children's changes in attitude toward environmental issues which occurred during the project appeared in their family life, which led to changes in their families. The children's increased environmental sensitivity, environmental awareness, and concern about environmental issues stimulated changes in other family members. The core axis of the program was the professional environmental education of university staff, and this led to significant changes in the children. Unlike the company, the university had a background of knowledge, experience, and know-how regarding environmental education. This knowledge was used in the development and application of the environmental education program, which led to changes in the attitudes of the participants toward environmental issues.

The company's role in the collaboration was to motivate participants, suggest the purpose of the project, recommend the range of participants, and to support the project financially. One valuable result of the project was that the company's perspective on CER (corporate environmental responsibility) changed. At the beginning of the project, the company had the idea that the contents of the project should include some elements of corporate promotion. As the project progressed, the company perceived that they could improve their public image more by offering mature environmental education. In fact, no modern enterprise can achieve long-term business success without the continuous understanding and support of local communities and other stakeholders (Moir \& Taffler, 2004). Through communication with universities, schools, and community members during this project, Hyundai Steel developed a more constructive understanding of and attitude toward environmental education.

One of the later achievements of the project was its expansion to include direct participation by various members of the community and not only students. Such ideas were not drawn with one stroke but constantly evolved and developed through interactions among stakeholders, including businesses, universities, teachers, local residents, and students. This evolution gradually led to the satisfaction of project participants (Table 2).

To improve the project, its contents as well as the range of participants were modified. In the initial study, the company's volition was the main motivation for the project, so the company's ideas (rather than the university's) were mostly reflected in decisions such as the object, scale, and operating method. Over time, the project changed organically to reflect the opinions of university staff, environmental education professionals, teachers, and community members. Figure 1 shows the collaborative model for this project as deduced from the evolutionary developments over three years. 


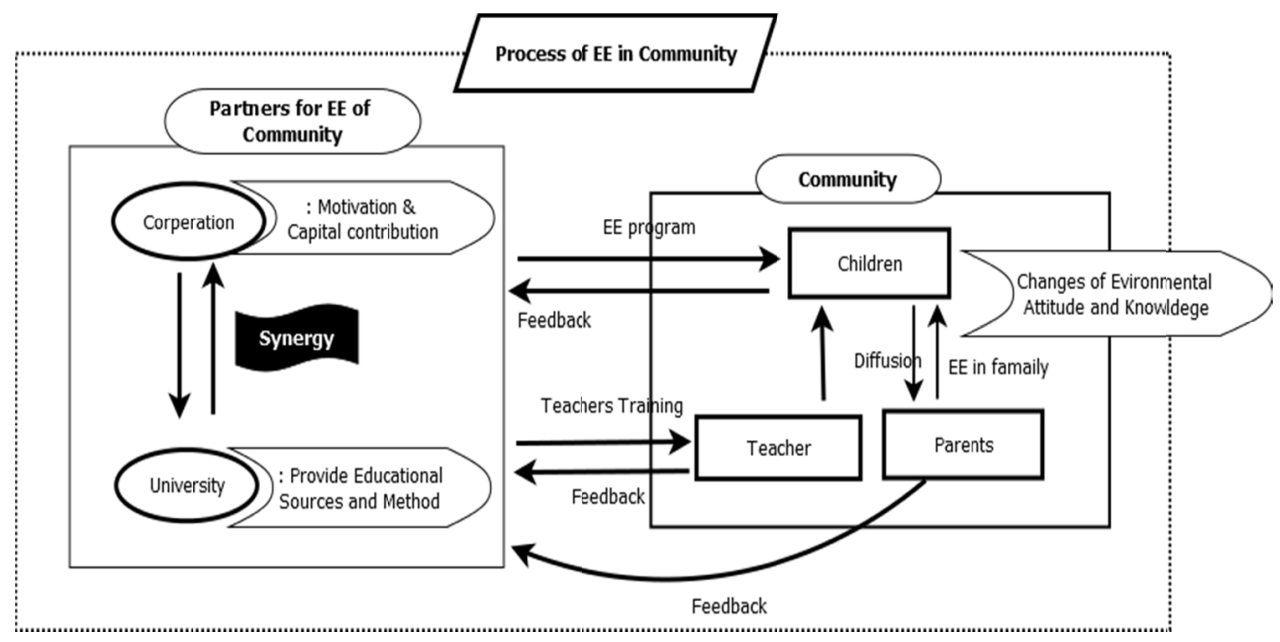

Figure 1. Collaborative process of program development

This model suggests how community environmental change of the community could be brought about through the increasing social responsibility of corporations. The results of this study will provide insight to corporations who wish to discharge their social obligations through environmental education or any groups who wish to conduct environmental education in a community.

\section{References}

Agyeman, J. (2003). "Under-Participation" and Ethnocentrism in Environmental Education Research: Developing "Culturally Sensitive Research Approaches". Canadian journal of environmental education, 8(1), 80-94.

Athman, J., \& Monroe, M. (2001). Elements of effective environmental education programs. In defining best practices in boating and fishing education (Edited by a. Fedler, pp. 37-48). Washington, DC:

Ballantyne, R., Connell, S., \& Fien, J. (1998). Students as catalysts of environmental change: A framework for researching intergenerational influence through environmental education. Environmental Education Research, 4(3), 285-298. https://doi.org/10.1080/1350462980040304

Ballantyne, R., Fien, J., \& Packer, J. (2001). School environmental education programme impacts upon student and family learning: A case study analysis. Environmental Education Research, 7(1), 23-37. https://doi.org/10.1080/13504620124123

Beder, S. (2002). Global spin: The corporate assault on environmentalism. Devon: Green Books.

Bortree, D. S., Ahern, L., Smith, A. N., \& Dou, X. (2013). Framing environmental responsibility: 30 years of CSR messages in National Geographic Magazine. Public Relations Review, 39(5), 491-496. https://doi.org/10.1016/j.pubrev.2013.07.003

Brothers, C. C. (1990). The impact of television on public environmental knowledge concerning the Great Lakes (Doctoral dissertation). The Ohio State University. US

Damerell, P., Howe, C., \& Milner-Gulland, E. J. (2013). Child-orientated environmental education influences adult knowledge and household behaviour. Environmental Research Letters, 8(1), 15-16. https://doi.org/10.1088/1748-9326/8/1/015016

Davis, J. J. (1994). Consumer response to corporate environmental advertising. Journal of Consumer Marketing, 11(2), 25-37. https://doi.org/10.1108/07363769410058902

DesJardins, J. (1998). Corporate environmental responsibility. Journal of Business Ethics, 17(8), 825-838. https://doi.org/10.1023/A:1005719707880

Dori, Y. J., \& Tal, R. T. (2000). Formal and informal collaborative projects: Engaging in industry with $\begin{array}{llll}\text { environmental awareness. } & \text { Science } & \text { Education, } & \text { 95-113. }\end{array}$ https://doi.org/10.1002/(sici)1098-237x(200001)84:1<95::aid-sce7>3.0.co;2-w

Gunningham, N. (2009). Shaping corporate environmental performance: A review. Environmental Policy and 
Governance, 19(4), 215-231. https://doi.org/10.1002/eet.510

Holtbrügge, D., \& Dögl, C. (2012). How international is corporate environmental responsibility? A literature review. Journal of International Management, 18(2), 180-195. https://doi.org/10.1016/j.intman.2012.02.001

Hungerford, H. R., \& Volk, T. L. (1990). Changing learner behavior through environmental education. The journal of environmental education, 21(3), 8-21. https://doi.org/10.1080/00958964.1990.10753743

Korean Statistical Information Service. (2016). Population Statistics Based on Resident Registration. Retrieved from March 25, 2016, from http://kosis.kr/statisticsList

Lee, Y. S. (2000). The sustainability of university-industry research collaboration: An empirical assessment. The Journal of Technology Transfer, 25(2), 111-133. https://doi.org/10.1023/A:1007895322042

Leeming, F. C., Dwyer, W. O., \& Bracken, B. A. (1995). Children's environmental attitude and knowledge scale: Construction and validation. The Journal of Environmental Education, 26(3), 22-31. https://doi.org/10.1080/00958964.1995.9941442

Maxwell, J., Rothenberg, S., Briscoe, F., \& Marcus, A. (1997). Green schemes: corporate environmental strategies and their implementation. California Management Review, 39(3), 118-134. https://doi.org/10.2307/41165902

Mazurkiewicz, P. (2004). Corporate environmental responsibility: Is a common CSR framework possible? In 24th annual IAIA conference, Vancouver, Bc.

Miles, M. P., \& Covin, J. G. (2000). Environmental marketing: a source of reputational, competitive, and financial advantage. Journal of business ethics, 23(3), 299-311. https://doi.org/10.1023/A:1006214509281

Ministry of Education. (2009). The national curriculum of Korea (2009 Revision). Ministry of Education. Korea

Moir, L., \& Taffler, R. (2004). Does corporate philanthropy exist?: business giving to the arts in the UK. Journal of Business Ethics, 54(2), 149-161. https://doi.org/10.1007/s10551-004-1777-1

Newton, B. J. (2001). Environmental education and outreach: experiences of a federal agency lessons learned by nrcs conservationists about the effectiveness of various education and outreach techniques can help scientists communicate better with the general public. BioScience, 51(4), 297-299. https://doi.org/10.1641/0006-3568(2001)051[0297:eeaoeo]2.0.co;2

Palmer, J. (2002). Environmental education in the 21st century: Theory, practice, progress and promise. Routledge. New York, US.

Perkmann, M., \& Walsh, K. (2009). The two faces of collaboration: impacts of university-industry relations on public research. Industrial \& Corporate Change, 18(6). https://doi.org/10.1093/icc/dtp015

Reyes, J., \& Twose, N. (2002). Education-focused corporate social responsibility in El Salvador. World Bank Technical Assistance Study, Washington DC.

Rondinelli, D. A., \& Berry, M. A. (2000). Environmental citizenship in multinational corporations: social responsibility and sustainable development. European Management Journal, 18(1), 70-84. https://doi.org/10.1016/s0263-2373(99)00070-5

Siegel, D. S., Waldman, D. A., Atwater, L. E., \& Link, A. N. (2003). Commercial knowledge transfers from universities to firms: Improving the effectiveness of university-industry collaboration. The Journal of High Technology Management Research, 14(1), 111-133. https://doi.org/10.1016/s1047-8310(03)00007-5

Slotte, V., \& Tynjälä, P. (2003). Industry-university collaboration for continuing professional development. Journal of Education and Work, 16(4), 445-464. https://doi.org/10.1080/1363908032000093058

Tali Tal, R. (2004). Community-based environmental education-a case study of teacher-parent collaboration. Environmental Education Research, 10(4), 523-543. https://doi.org/10.1080/1350462042000291047

Tener, R. K. (1996). Industry-university partnerships for construction engineering education. Journal of Professional Issues in Engineering Education and Practice, 122(4), 156-162. https://doi.org/10.1061/(ASCE)1052-3928(1996)122:4(156)

Vaughan, C., Gack, J., Solorazano, H., \& Ray, R. (2003). The effect of environmental education on schoolchildren, their parents, and community members: A study of intergenerational and intercommunity learning. The Journal of Environmental Education, 34(3), 12-21. https://doi.org/10.1080/00958960309603489 


\section{Copyrights}

Copyright for this article is retained by the author(s), with first publication rights granted to the journal.

This is an open-access article distributed under the terms and conditions of the Creative Commons Attribution license (http://creativecommons.org/licenses/by/4.0/). 